\title{
THE EFFECT OF MEDICINES WITH GOUTWEED (AEGOPODIUM PODAGRARIA L.) ON THE PHYSICAL ENDURANCE, COGNITIVE FUNCTIONS AND THE LEVEL OF DEPRESSION IN ANIMALS
}

\author{
O.V.Tovchiga, S.Yu.Shtrygol' \\ National University of Pharmacy
}

Key words: goutweed (Aegopodium podagraria L.); extract; tincture; central nervous system; physical endurance

The effect of the extract $(100 \mathrm{mg} / \mathrm{kg}$ and $1 \mathrm{~g} / \mathrm{kg}$ ) and the tincture (1 and $5 \mathrm{ml} / \mathrm{kg}$ ) of the goutweed (Aegopodium podagraria L.) aerial part on the physical endurance, the level of depression and cognitive functions has been studied using the weight-loaded forced swimming test, the extrapolation escape test, and the reserpine-induced depression model. The goutweed extract in the dose of $100 \mathrm{mg} / \mathrm{kg}$, but not in the dose of $1 \mathrm{~g} / \mathrm{kg}$, significantly increases the exhaustive swimming time $110 \%$ and $20 \%$ load) in male mice. In female mice the augmentation of exhaustive swimming time is registered with $20 \%$ load against the background of the extract in both doses. The goutweed tincture does not change the results of this test. Goutweed medicines have the ambiguous effect on the results of the extrapolation escape test: the extract and the tincture do not change the percentage of mice that succeed in completing the task, still the average time spent for the task performance is significantly decreased in these animals (but not within the whole group) against the background of the extract in the doses of $100 \mathrm{mg} / \mathrm{kg}$ and $1 \mathrm{~g} / \mathrm{kg}$. The extract in the dose of $100 \mathrm{mg} / \mathrm{kg}$ significantly reduces the number of rats capable of completing the task, the extract $(1 \mathrm{~g} / \mathrm{kg})$ and the tincture $(1 \mathrm{ml} / \mathrm{kg})$ increase the time spent for performing the extrapolation escape task by rats. The extract and the tincture do not change the body temperature reduction and blepharoptosis induced by reserpine in rats. Thus, the goutweed extract is able to increase the physical endurance, exert a moderate positive effect on cognitive functions in mice (but not in rats) without any significant changes in the level of depression. The goutweed tincture worsens the results of the extrapolation escape test in the dose of $1 \mathrm{ml} / \mathrm{kg}$, does not change them in the dose of $5 \mathrm{ml} / \mathrm{kg}$ and does not influence on the level of depression and physical endurance in both doses.

According to the WHO forecast, in 2020 depression will become the second leading cause of disability, therefore, considerable efforts are directed towards the improvement of the methods of its treatment [15], including the study of the promising herbal drugs. Besides antidepressants of the plant origin traditionally used (such as Hypericum perforatum L., Clusiaceae), herbal drugs (HD) combining a favourable metabolic activity and a mild psychotropic effect have arisen a great interest. On the one hand, the complex composition of crude HD is a prerequisite enabling useful concomitant effects, among which the psychotropic action may be supposed. On the other hand, for the HD that are used or planned to be used in chronic diseases for a long time the safety verification, including effects on the CNS, is particularly relevant.

Our research focuses on the verification of pharmacological properties of goutweed (Aegopodium podagraria $L$. Apiaceae, $\mathrm{GW}$ ) since the drugs obtained from this plant have long been used in folk medicine for the treatment of kidney diseases and metabolic disorders [3]. The dry extract and the tincture were obtained from the $\mathrm{GW}$ aerial part, their favourable effect on the purine metabolism, the carbohydrate metabolism, as well as a significant nephroprotective and hepatoprotective activity of the extract and its ability to counteract the effects of ethanol were shown $[2,4,7]$. The study of the psychotropic effects of these medicines in intact mice was started [17], and the antidepressant action of the extract (in the dose of $100 \mathrm{mg} / \mathrm{kg}$, but not in the dose of $1 \mathrm{~g} / \mathrm{kg}$ in female mice) with worsening of the results of the passive avoidance response (PAR) test was registered. The tendency towards reduction of anxiety signs in animals of both sexes against the background of the extract in the dose of $100 \mathrm{mg} / \mathrm{kg}$ (in males also against the background of the extract in the dose of $1 \mathrm{~g} / \mathrm{kg}$ and the tincture in the doses of 1 and $5 \mathrm{ml} / \mathrm{kg}$ ) was also registered. As evidenced from the foregoing, it is expedient to continue the study of the effect of GW medicines on the level of the animals' depression, as well as on the cognitive processes. Taking into consideration the favourable metabolic activity of GW medicines $[2,7]$ and the extract ability to decrease duration of immobility of animals [17] it is also efficient to determine the effect of these herbal medicines on the physical performance.

The aim of this study was to evaluate the efficacy of medicines with $A$. podagraria $L$. in the weight-loaded forced swimming test, the extrapolation escape test, as well as reserpine-induced depression. 


\section{Materials and Methods}

The dry extract and the tincture were obtained from $A$. podagraria $L$. aerial part using the standard method described previously in accordance with the requirements of the State Pharmacopoeia of Ukraine [2, 7].

All the experiments were conducted according to the principles of bioethics as required in the "Directive 2010/ 63/EU of the European Parliament and of the Council of September, 22, 2010 on the protection of animals used for scientific purposes." Albino male rats with the body weight of 180-220 $\mathrm{g}$ and albino male mice with the body weight of 16-22 g were kept in the Central Research Laboratory of the National University of Pharmacy under standard conditions. As the gender specific effect of GW medicines on the immobility time was registered [17], female mice with the body weight of 18-24 $\mathrm{g}$ were also used in the weight-loaded forced swimming test.

In all the experiments discussed GW medicines, namely the extract as a water solution in the doses of $100 \mathrm{mg} / \mathrm{kg}$ and $1 \mathrm{~g} / \mathrm{kg}$ and the tincture, from which ethyl alcohol was previously removed, in the doses of 1 and $5 \mathrm{ml} / \mathrm{kg}$ were administered to mice or rats intragastrically in the preventive mode. The animals of the intact control groups received the same amount of water. The last dose of these medicines (or water) in all the experiments was administered 40 min before beginning of the tests or reserpine administration.

The weight-loaded forced swimming test was conducted after the course of administration of GW medicines ( 10 doses). The metal load ( $10 \%$ of the body weight) was fixed on the tail root of each mouse, and the animals were placed individually into the pool with water at $22-23^{\circ} \mathrm{C}$. The pool was filled with $60 \mathrm{~cm}$ water, the pool ledges equalled $15 \mathrm{~cm}$ over the water level without allowing the rest of the animal on them. The swimming time to exhaustion was recorded by the criterion of head dip under water without coming to the water surface for $10 \mathrm{~s}$ [1]. To determine the stability of the effect and its limits one day after the test was repeated with $20 \%$ load. In this test additional groups of mice were used. They received such reference drugs as the extract of St. John's wort (Hypericum perforatum L., Clusiaceae) ("Deprivit" from Kyiv Vitamin Factory, Ukraine) as a herbal drug being effective in the experimental pharmacology [14] with the proven ability to stimulate the CNS in the dose of $100 \mathrm{mg} / \mathrm{kg}$ intragastrically, and the extract of Passiflora incarnata L. (Passifloraceae) as "Alora" syrup (NOBEL ILAC Sanayii ve Ticaret A.S., Turkey) being effective according to the data [12] in the dose of $300 \mathrm{mg} / \mathrm{kg}$ intragastrically. The latter was used as a reference drug because in the previous experiments the reduction of anxiety signs in animals receiving the GW extract and the passionflower extract appeared to be similar [17]. Besides, along with the extract of $H$. perforatum $L$., which mainly leads to the CNS activation [14], it is expedient to use other well studied and practically applied reference drug, which main psychotropic effects are anxiolytic and sedative [12].

The cognitive functions of mice and rats receiving GW medicines (the course lasted 7 days) were assessed by extrapolation escape test registering the latency of escape (avoidance through diving) of the animal placed to the cylinder with the edge under water as described in [11]. The test period was limited to $120 \mathrm{~s}$ (mice) and $180 \mathrm{~s}$ (rats), and the number of animals performed the task was recorded. In these experiments 5 groups of mice and 5 groups of rats were used (the control group and animals receiving GW medicines in the doses mentioned).

In the experiments in rats the efficacy of GW medicines (the course of preventive administration lasted 7 days) was also determined under the conditions of a single intraperitoneal administration of reserpine in the dose of $4 \mathrm{mg} / \mathrm{kg}$. The depressogenic effect of reserpine was assessed in $7 \mathrm{~h}$ using the criteria of the decrease in the body temperature (rectal measurement) and the blepharoptosis rate (the degree of ptosis was rated according to the following rating scale: 0 - complete absence of ptosis, 1 - eyes are half closed, 2 - the eye closure is more than on $1 / 2,3$ - eyes are completely closed) $[6,9]$.

Proceeding from the modern requirements for medical and biological data analysis [15], medians, $25 \%$ and $75 \%$ percentiles (upper and lower quartiles) were calculated.

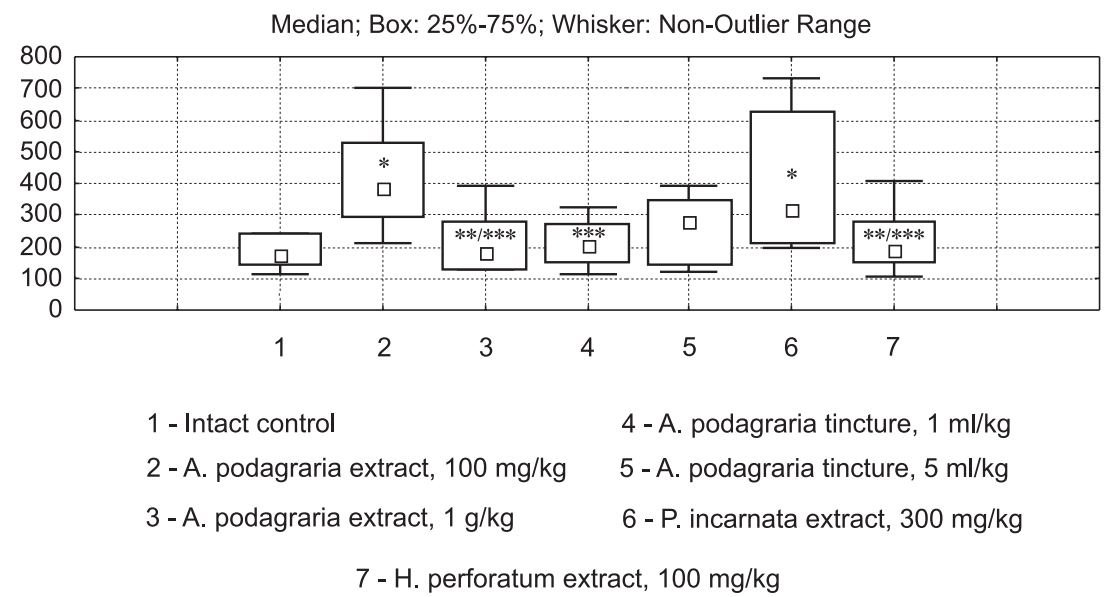

Fig. 1. The effect of medicines with Aegopodium podagraria $L$. and reference drugs on the physical endurance of male mice in the weightloaded ( $10 \%$ of the body weight) forced swimming test, seconds. * - statistically significant differences compared to the intact control group, $p<0.05 ;{ }^{* *}$ - statistically significant differences compared to the group receiving the extract of Aegopodium podagraria $L$. in the dose of $100 \mathrm{mg} / \mathrm{kg}, \mathrm{p}<0.02 ;{ }^{* * *}$ - statistically significant differences compared to the group receiving the extract of Passiflora incarnata $L ., p<0.05$. 


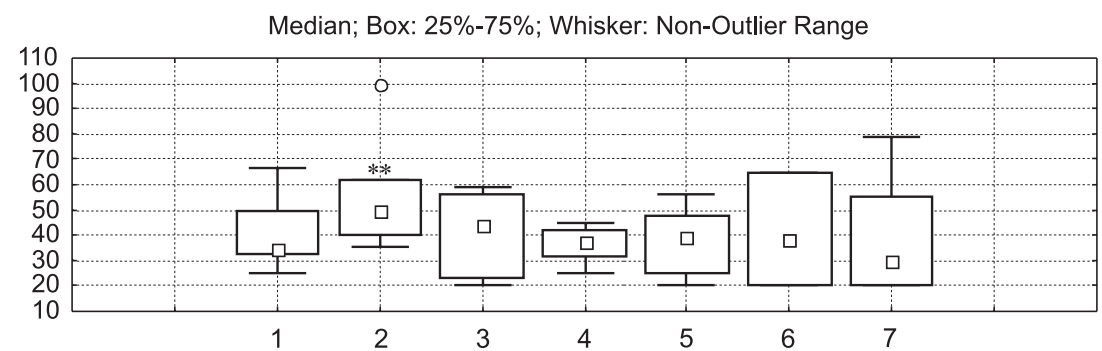

1 - Intact control

2 - A. podagraria extract, $100 \mathrm{mg} / \mathrm{kg}$

3 - A. podagraria extract, $1 \mathrm{~g} / \mathrm{kg}$
4 - A. podagraria tincture, $1 \mathrm{ml} / \mathrm{kg}$

5 - A. podagraria tincture, $5 \mathrm{ml} / \mathrm{kg}$

6 - P. incarnata extract, $300 \mathrm{mg} / \mathrm{kg}$

7 - H. perforatum extract, $100 \mathrm{mg} / \mathrm{kg}$

Fig. 2. The effect of medicines with Aegopodium podagraria $L$. and reference drugs on the physical endurance of male mice in the weight-loaded ( $20 \%$ of the body weight) forced swimming test, seconds. ${ }^{* *}-$ statistically significant differences compared to the intact control group, $\mathrm{p}<0.02$.

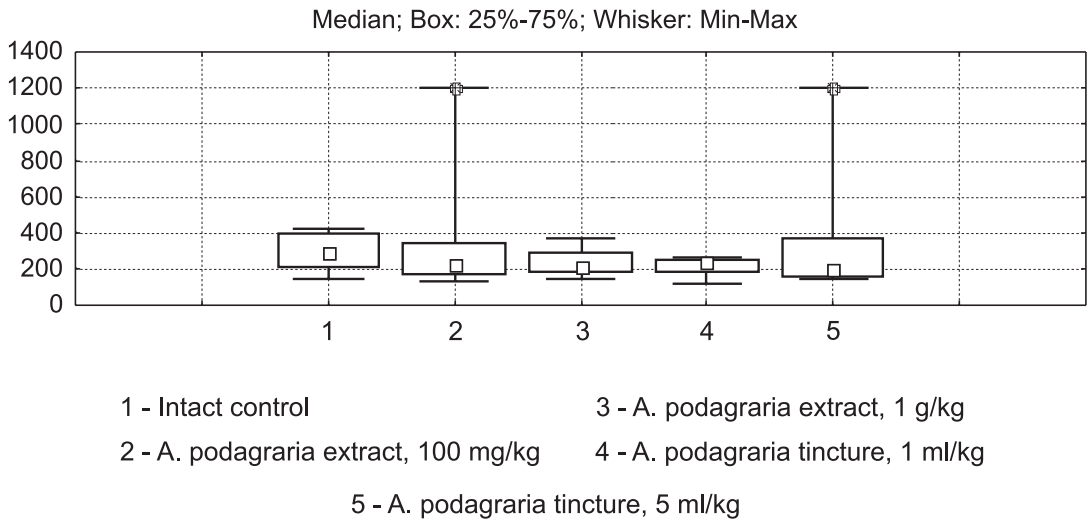

Fig. 3. The effect of medicines with Aegopodium podagraria L. on the physical endurance of female mice in the weight-loaded ( $10 \%$ of body weight) forced swimming test, seconds.

Traditionally used means \pm standard errors of the mean (SEM) are also presented $(\mathrm{M} \pm \mathrm{m})$. Central tendencies of the independent samples were compared using the MannWhitney U test, intergroup differences (the body temperature before and after reserpine administration) were analysed using the Wilcoxon matched pairs $\tilde{T}$ test, and the Fisher's angular transformation was used for comparing data represented in alternative forms.

\section{Results and Discussion}

The weight-loaded forced swimming test is a generally accepted test for the study of physical endurance of animals [1], but its results can be changed significantly in animals receiving psychotropic drugs (such as stimulation of motor activity against the background of medicines that activate the CNS, and decrease in physical performance after administration of sedative and anxiolytic drugs [8]). As shown in Fig. 1 and Fig. 2, the GW extract in the dose of $100 \mathrm{mg} / \mathrm{kg}$, but not in the dose of $1 \mathrm{~g} / \mathrm{kg}$, significantly increased duration of swimming to exhaustion in male mice for both regimens used. In female mice receiving the GW extract in both doses the effect was manifested only when $20 \%$ load was used (Fig. 3, Fig. 4, with 10\% load only drastic augmentation of physical performance in certain animals was seen after administration of the extract in the lower dose and the tincture in the high dose). The mechanism of action of the extract (which requires further research) can be associated with favourable peripheral metabolic effects (hypoazotemic action, optimization of the glucose metabolism, cytolysis counteraction, etc., though they are more marked against the background of the extract in the high dose $[2,7])$, as well as with the psychotropic activity of this medicine. The latter assumption is indirectly supported by the data about the decrease in duration of immobility and a tendency towards reduction of anxiety signs in mice receiving this herbal medicine in the dose of $100 \mathrm{mg} / \mathrm{kg}$ [17] and the presence of the extract effect during the second session of swimming in mice since it is known that the effect on the level of depression is revealed just in the repeated tests [16]. As to the reference drugs $H$. perforatum $L$. extract did not significantly affect duration of swimming in male mice, while $P$. incarnata $L$. extract increased this value (statistically significant increase in the test with $10 \%$ load and a tendency in the test with $20 \%$ load). In most studies available the effect of these well-studied herbal drugs was determined in the forced swimming test with registration of the swimming and immobilization time for a certain period, but not with the general duration of swimming. According to these data both reference drugs increased duration of swimming in the doses similar to those used in our study, namely $70 \mathrm{mg} / \mathrm{kg}$ for the extract of $\mathrm{H}$. per- 


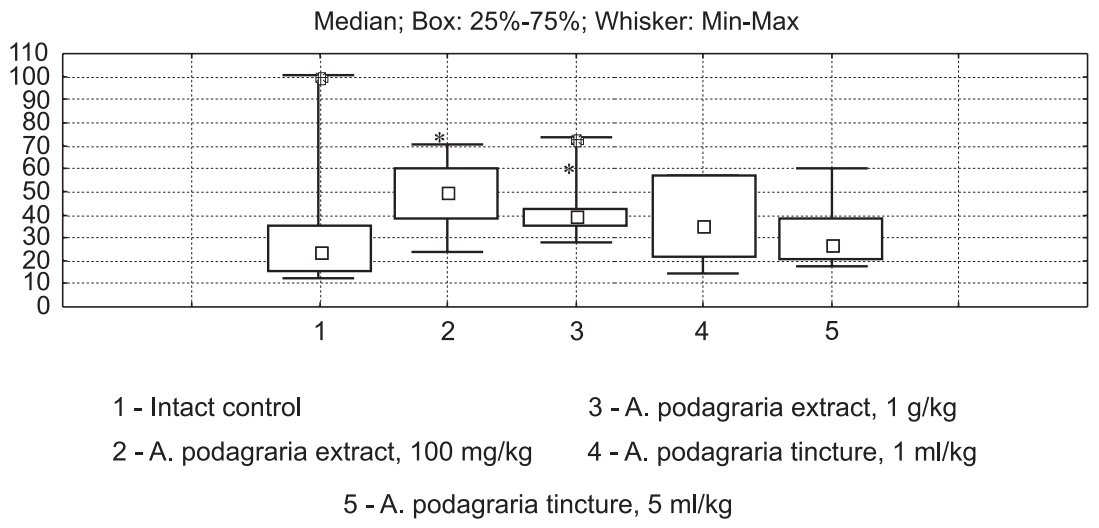

Fig. 4. The effect of of medicines with Aegopodium podagraria $L$. on the physical endurance of female mice in the weight-loaded $(20 \%$ of body weight) forced swimming test, seconds. * ${ }^{*}$ statistically significant differences compared to the intact control group, $p<0.05$.

foratum L. (but after a single administration) [10], 200 and $400 \mathrm{mg} / \mathrm{kg}$ for the extract of P. incarnata L. [13].

The extrapolation escape test characterizing the ability of an animal to find a way out in the acute stressful situation [11] was conducted to broaden the data about psychotropic effects of the medicines studied since previously it was shown that there was a worsening in PAR test results in female (but not in male) mice against the background of the extract in the dose of $100 \mathrm{mg} / \mathrm{kg}$; exactly in this dose the extract decreased duration of immobility and tended to reduce the signs of anxiety [17]. As shown in Tab. 1, GW medicines did not influence on the results of this test in mice (only a tendency towards worsening of the results was observed against the background of the tincture in the lower dose); however, after administration of the extract in the dose of $100 \mathrm{mg} / \mathrm{kg}$ in rats there was a significant reduction in the number of animals that were able to escape. In addition, augmentation of the time spent for performing the task was regis- tered in rats under the influence of the extract in a high dose and the tincture in a low dose. However, the time spent for performing the task in animals that were able to escape tended to decrease in rats receiving the extract in the dose of $100 \mathrm{mg} / \mathrm{kg}$ (with the opposite change in animals treated with this medicine in the dose of $1 \mathrm{~g} / \mathrm{kg}$ ) and also was significantly reduced in groups of mice receiving the extract in both doses. Thus, summarizing the experimental data of the present and previous works [17] shows that the lowering of anxiety signs and emotional reactions (grooming) in male mice receiving the $\mathrm{GW}$ extract is not accompanied with negative changes in the results of both PAR and extrapolation escape test.

The extrapolation escape test is widely used for the research of nootropic drugs under complicated conditions (stressful situation, trauma, effect of toxins, etc.), but there is no information in the available literature about the effect of herbal biologically active substances on the results of this test. Taking into account interspecies diffe-

Table 1

The effect of medicines with Aegopodium podagraria L. on the results of the extrapolation escape test in male rats and male mice, $\mathrm{M} \pm \mathrm{m} ; \mathbf{Q}_{50}\left(\mathbf{Q}_{25}-\mathbf{Q}_{75}\right)$

\begin{tabular}{|c|c|c|c|c|c|c|}
\hline \multirow[b]{3}{*}{ Group } & \multicolumn{3}{|c|}{ Rats } & \multicolumn{3}{|c|}{ Mice } \\
\hline & \multicolumn{2}{|c|}{ Latency of escape, $\mathrm{s}$} & \multirow{2}{*}{$\begin{array}{c}\text { Number of } \\
\text { animals that } \\
\text { were able } \\
\text { to escape, } \\
\% \text { (absolute } \\
\text { number) }\end{array}$} & \multicolumn{2}{|c|}{ Latency of escape, $\mathrm{s}$} & \multirow{2}{*}{$\begin{array}{c}\text { Number of } \\
\text { animals that } \\
\text { were able } \\
\text { to escape, } \\
\% \text { (absolute } \\
\text { number) }\end{array}$} \\
\hline & $\begin{array}{l}\text { In the whole } \\
\text { group }\end{array}$ & $\begin{array}{c}\text { Among } \\
\text { animals that } \\
\text { were able to } \\
\text { escape }\end{array}$ & & $\begin{array}{l}\text { In the whole } \\
\text { group }\end{array}$ & $\begin{array}{c}\text { Among } \\
\text { animals that } \\
\text { were able to } \\
\text { escape }\end{array}$ & \\
\hline $\begin{array}{l}\text { Intact control, } \\
n=9, n=8\end{array}$ & \multicolumn{2}{|c|}{$\begin{array}{c}44 \pm 17 \\
21(15-26)\end{array}$} & $100(9 / 9)$ & $\begin{array}{c}28 \pm 13 \\
15(14-18)\end{array}$ & $\begin{array}{c}15 \pm 2 \\
15(13-16)\end{array}$ & $88(7 / 8)$ \\
\hline $\begin{array}{l}\text { A. podagraria extract, } \\
100 \mathrm{mg} / \mathrm{kg}, \mathrm{n}=6, \mathrm{n}=8\end{array}$ & $\begin{array}{c}101 \pm 36 \\
110(21-180)\end{array}$ & $\begin{array}{c}21 \pm 9 \\
15(12-28)\end{array}$ & $50(3 / 6)^{*}$ & $\begin{array}{l}29 \pm 15 \\
9(7-26)\end{array}$ & $\begin{array}{c}16 \pm 8 \\
8(7-12)^{*}\end{array}$ & $88(7 / 8)$ \\
\hline $\begin{array}{l}\text { A. podagraria extract, } \\
1 \mathrm{~g} / \mathrm{kg}, \mathrm{n}=6, \mathrm{n}=8\end{array}$ & $\begin{array}{c}99 \pm 29 \\
89(41-166)^{*}\end{array}$ & $\begin{array}{c}59 \pm 22 \\
46(33-73) \\
\end{array}$ & $67(4 / 6)$ & $\begin{array}{c}36 \pm 18 \\
10(6-40)\end{array}$ & $\begin{array}{c}8 \pm 2 \\
6(6-11)^{* *}\end{array}$ & $75(6 / 8)$ \\
\hline $\begin{array}{l}\text { A. podagraria tincture, } \\
1 \mathrm{ml} / \mathrm{kg}, \mathrm{n}=5, \mathrm{n}=8\end{array}$ & $\begin{array}{c}114 \pm 36 \\
160(27-180)^{*}\end{array}$ & $\begin{array}{c}71 \pm 45 \\
27(26-94)\end{array}$ & $60(3 / 5)$ & $\begin{array}{c}59 \pm 20 \\
47(8-120)\end{array}$ & $\begin{array}{l}23 \pm 16 \\
8(6-8)\end{array}$ & $63(5 / 8)$ \\
\hline $\begin{array}{l}\text { A. podagraria tincture, } \\
5 \mathrm{ml} / \mathrm{kg}, \mathrm{n}=7, \mathrm{n}=8\end{array}$ & $\begin{array}{c}45 \pm 23 \\
26(16-37)\end{array}$ & $\begin{array}{c}23 \pm 5 \\
22(15-33)\end{array}$ & $86(6 / 7)$ & $\begin{array}{c}23 \pm 14 \\
10(5-16)\end{array}$ & $\begin{array}{c}9 \pm 2 \\
9(5-13)\end{array}$ & $88(7 / 8)$ \\
\hline
\end{tabular}

Notes: ${ }^{*}$ - statistically significant differences compared to the intact control group, $p<0.05$; ${ }^{* *}$ - statistically significant differences compared to the intact control group, $\mathrm{p}<0.01$. 
The effect of medicines with Aegopodium podagraria L. on the body temperature decrease and blepharoptosis in reserpine-treated rats, $\mathrm{M} \pm \mathrm{m} ; \mathbf{Q}_{50}\left(\mathbf{Q}_{25}-\mathbf{Q}_{75}\right)$

\begin{tabular}{|c|c|c|c|c|}
\hline \multirow[b]{2}{*}{ Group } & \multicolumn{2}{|c|}{ Body temperature, ${ }^{\circ} \mathrm{C}$} & \multirow[b]{2}{*}{$\begin{array}{c}\text { Body temperature } \\
\text { decrease, }{ }^{\circ} \mathrm{C}\end{array}$} & \multirow[b]{2}{*}{$\begin{array}{c}\text { Blepharoptosis, } \\
\text { points }\end{array}$} \\
\hline & basal level & $\begin{array}{l}4 \text { hours after } \\
\text { reserpine } \\
\text { administration }\end{array}$ & & \\
\hline Intact control, $\mathrm{n}=8$ & $\begin{array}{c}38.9 \pm 0.08 \\
38.9(38.8-39.0) \\
\end{array}$ & $\begin{array}{c}38.1 \pm 0.21 \\
38.2(38.0-38.4)^{* *}\end{array}$ & $\begin{array}{c}0.7 \pm 0.3 \\
0.7(0.2-1.0)\end{array}$ & $\begin{array}{c}2.0 \pm 0.4 \\
2.0(1.8-3.0)\end{array}$ \\
\hline A. podagraria extract, $100 \mathrm{mg} / \mathrm{kg}, \mathrm{n}=6$ & $\begin{array}{c}39.3 \pm 0.09 \\
39.3(39.1-39.5) \\
\end{array}$ & $\begin{array}{c}38.3 \pm 0.18 \\
38.2(38.0-38.4)^{*} \\
\end{array}$ & $\begin{array}{c}1.0 \pm 0.2 \\
1.1(0.9-1.3) \\
\end{array}$ & $\begin{array}{c}1.8 \pm 0.5 \\
2.0(1.3-2.8)\end{array}$ \\
\hline A. podagraria extract, $1 \mathrm{~g} / \mathrm{kg}, \mathrm{n}=7$ & $\begin{array}{c}39.3 \pm 0.12 \\
39.4(39.2-39.5)\end{array}$ & $\begin{array}{c}38.3 \pm 0.30 \\
38.4(37.8-39.1)^{*}\end{array}$ & $\begin{array}{c}1.0 \pm 0.3 \\
1.0(0.3-1.6)\end{array}$ & $\begin{array}{c}1.4 \pm 0.4 \\
2.0(0.5-2.0) \\
\end{array}$ \\
\hline A. podagraria tincture, $1 \mathrm{ml} / \mathrm{kg}, \mathrm{n}=7$ & $\begin{array}{c}39.3 \pm 0.10 \\
39.2(39.2-39.3)\end{array}$ & $\begin{array}{c}38.2 \pm 0.20 \\
38.1(37.9-38.6)^{*}\end{array}$ & $\begin{array}{c}1.1 \pm 0.2 \\
1.2(1.1-1.3)\end{array}$ & $\begin{array}{c}1.2 \pm 0.4 \\
1.0(0.5-2.0)\end{array}$ \\
\hline A. podagraria tincture, $5 \mathrm{ml} / \mathrm{kg}, \mathrm{n}=7$ & $\begin{array}{c}39.1 \pm 0.20 \\
39.1(39.1-39.3)\end{array}$ & $\begin{array}{c}38.3 \pm 0.11 \\
38.3(38.1-38.5)^{* *}\end{array}$ & $\begin{array}{c}0.8 \pm 0.1 \\
0.8(0.6-1.0)\end{array}$ & $\begin{array}{c}0.9 \pm 0.3 \\
1.0(0-1.5)\end{array}$ \\
\hline
\end{tabular}

Notes: ${ }^{*}$ - statistically significant differences compared to the basal level, $\mathrm{p}<0.05 ;{ }^{* *}$ - statistically significant differences compared to the basal level, $\mathrm{p}<0.02$.

rences and the possible absence of correlation between the results of different psychopharmacological tests, including PAR and extrapolation escape test (and the concept about the dependence of PAR results on the overall strategy of animal's behaviour [5], that is likely to be changed under the influence of herbal drugs eliminating anxiety and depression signs), further studies of psychotropic effects of GW medicines are expedient (especially in female animals because of more significant changes in their behavioural reactions [17]).

The test of interaction with reserpine that causes depletion of catecholamines is commonly used for elucidation of the mechanism of action of psychotropic drugs from different groups despite the absence of high selectivity of reserpine [6]. As can be seen from Tab. 2, reserpine significantly reduced the body temperature of animals and caused blepharoptosis, the results obtained were comparable with the data in the literature [9]. There were no intergroup differences in the parameters studied (only a tendency towards blepharoptosis reduction was present against the background of the GW tincture). Hence, the effect of GW biologically active substances is probably not related to catecholaminergic mechanisms. Since the GW extract can decrease duration of immobility of animals, further studies of its mechanisms of action are expedient.

\section{CONCLUSIONS}

1. In the weight-loaded forced swimming test the extract of Aegopodium podagraria L. in the dose of $100 \mathrm{mg} / \mathrm{kg}$, but not in the dose of $1 \mathrm{~g} / \mathrm{kg}$, significantly increases the physical endurance in male mice (with $10 \%$ and $20 \%$ load used). In female mice this effect is registered with $20 \%$ load against the background of the extract in the doses of $100 \mathrm{mg} / \mathrm{kg}$. The tincture of Aego-podium podagraria $L$. does not cause a favourable effect on the physical endurance.

2. The extract and tincture of Aegopodium podagraria $L$. do not change the percentage of mice that succeed in completing the extrapolation escape task; however, among these animals (but not within the whole group) the extract in the doses of $100 \mathrm{mg} / \mathrm{kg}$ and $1 \mathrm{~g} / \mathrm{kg}$ significantly decreases the latency of escape, indicating moderate nootropic properties. However, the extract in the dose of $100 \mathrm{mg} / \mathrm{kg}$, in contrast, significantly reduces the number of rats capable of completing the task; the extract in the dose of $1 \mathrm{~g} / \mathrm{kg}$ and the tincture in the dose of $1 \mathrm{ml} / \mathrm{kg}$ increase the time spent for the task performance in rats.

3. The extract and tincture of Aegopodium podagraria $L$. do not influence on the decrease in the body temperature and blepharoptosis caused by reserpine in rats, and therefore, do not exhibit antidepressant properties.

\section{REFERENCES}

1. Експериментальне вивчення нових адаптогенних засобів: Метод. рекоменд. / Л.В.Яковлєва, О.Я.Міщенко, Ю.Б.Лар'яновська та ін. - К., 2009. - 37 с.

2. Койро О.О.: автореф. дис. ... канд. фарм. наук. - Х., 2014. - 20 с.

3. Лікарські рослини: Енииклопед. довід. / Відп. ред. А.М.Гродзинський. - К.: Голов. ред. УРЕ, 1990. - С. 487.

4. Пат. на кор. модель 95127 Украӥна, МПК А 61 P 25/32 (2006.01), А 61 K 36/23(2006.01) / О.В.Товчига, С.Ю.Штриголь, В.А.Товчига; заявник та власник НФаУ. - № и 2014 07336. Заявл.: 01.07.2014. Опубл.: 10.12.2014. - Бюл. №23/2014.

5. Райт Д.В., Грошев Д.С. Матер. Междунар. молодежного научного форума «ЛОМОНОСОВ-2014». М.: МАКС Пресс, 2014. - С. 7-8. 
6. Руководство по экспериментальному (доклиническому) изучению новых фармакологических веществ / Под общ. ред. чл.-кор. РАМН, проф. Р.У.Хабриева. - М.: Мед., 2005. - С. 247.

7. Товчига O.В.: автореф. дис. ... канд. фарм. наук. - Х., 2009. - 21 с.

8. Тюренков И.Н., Меркушенкова О.В., Багметова В.В. // Вестник ВолГМУ. - 2008. - №4 (28). - С. 83-86.

9. Щокіна К.Г., Штриголь С.Ю., Іщенко О.М., Бухтіярова І.П. // Вісник фармачії. - 2010. - №4 (64). - С. 71 -74.

10. Bach-Rojecky L., Kalodjera Z., Samarzija I. // Acta Pharm. - 2004. - Vol. 54, №2. - P. 157-162.

11. Bondarenko N.A., Miroshnichenko I.I., Kudrin V.S. // Bull. Exp. Biol. Med. - 1990. - Vol. 110, №11. - P. 506-508.

12. Deng J., Zhou Y., Bai M. et al. // J. Ethnopharmacol. - 2010. - Vol. 128, №1. - P. 148-153.

13. Jafarpoor N., Abbasi-Maleki S., Asadi-Samani M., Khayatnouri M.H. // J. Herb Med. Pharmacol. - 2014. Vol. 3, №1. - P. 41-45.

14. Kumar V., Singh P.N., Jaiswal A.K., Bhattacharya S.K. // Ind. J. Exp. Biol. - 1999. - Vol. 37, №12. - P. 1171-1176.

15. Mental health: a call for action by world health ministers / WHO background document. - Geneva: WHO, 2001. - 23 p.

16. Sun M.K., Alkon D.L. // J. Neurosci Meth. - 2003. - Vol. 126. - P. 35-40.

17. Tovchiga O., Shtrygol'S. // J. Chem. Pharm. Res. - 2015. - Vol. 7, №7. - P. 370-384.

18. Weissgerber T.L., Milic N.M., Winham S.J., Garovic V.D. // PLOS Biol. - 2015. - Vol. 13, №4. - Art. e1002128.

ВПЛИВ ПРЕПАРАТІВ ЯГЛИЦІ ЗВИЧАЙНОÏ (AEGOPODIUM PODAGRARIA L.) НА ФІЗИЧНУ ВИТРИВАЛІСТЬ, КОГНІТИВНІ ФУНКЦІЇ ТА ДЕПРЕСИВНІСТЬ ТВАРИН

О.В.Товчига, С.Ю.Штриголь

Ключові слова: яглиця звичайна (Aegopodium podagraria L.); екстракт; настойка;

центральна нервова система; фрізична витривалість

Досліджено вплив екстракту (100 мг/кг та 1 г/ка) та настойки (1 та 5 мл/кг) надземної частини яглиці звичайної Aegopodium podagraria L. на фрізичну працездатність, депресивність, когнітивні процеси у тестах плавання з навантаженням, екстраполяційного позбавлення і резерпінової депресії. Екстракт яглиці в дозі 100 мг/ке, але не 1 г/ке, достовірно підвищує час плавання 3 навантаженням (10\% та 20\%) у мишей-самців. У мишей-самок час плавання збільшується за використання навантаження 20\% на тлі екстракту в обох дозах. Настойка яглиці не змінює результати даного тесту. Препарати яглиці неоднозначно впливають на результати тесту екстраполяційного позбавлення: екстракт та настойка не змінюють кількість мишей, що успішно виконують тест, однак достовірно знижується час позбавлення серед цих тварин (але не серед усієї групи) на тлі екстракту в дозах 100 мг/ке та 1 г/ке. Екстракт (100 мг/к己) достовірно знижує кількість щурів, які здійснюють пірнання, екстракт (1 г/к己) та настойка (1 мл/кг) збільшують час виконання даного тесту щурами. Екстракт та настойка не змінюють вираженість зниження температури тіла та блефрароптозу, спричинених резерпіном у щурів. Отже, екстракт яглиці здатен підвищувати фрізичну працездатність, чинити помірний позитивний вплив на когнітивні процеси в мишей (але не у щурів) без суттєвих змін депресивності. Настойка яглиці погіршує результати тесту екстраполяційного позбавлення в дозі 1 мл/ке, не змінює їх у дозі 5 мл/ке, не впливає на депресивність та фрізичну працездатність в обох дозах.

\section{ВЛИЯНИЕ ПРЕПАРАТОВ СНЫТИ ОБЫКНОВЕННОЙ (AEGOPODIUM PODAGRARIA L.) HA ФИЗИЧЕСКУЮ ВЫНОСЛИВОСТЬ, КОГНИТИВНЫЕ ФУНКЦИИ И ДЕПРЕССИВНОСТЬ ЖИВОТНЫХ О.В.Товчига, С.Ю.Штрыголь}

Ключевые слова: сныть обыкновенная (Aegopodium podagraria L.); экстракт; настойка; центральная нервная система; фризическая работоспособность Исследовано влияние экстракта (100 мг/кг и 1 2/к2), а также настойки (1 и 5 мл/кг) надземной части сныти обыкновенной Aegopodium podagraria L. на фризическую работоспособность, депрессивность, когнитивные процессы в тестах плавания с нагрузкой, экстраполяционного избавления и резерпиновой депрессии. Экстракт сныти в дозе 100 мг/ке, но не 1 г/ка, достоверно увеличивает длительность плавания с нагрузкой (10\% и 20\%) у мышей-самцов. У мышей-самок возрастание длительности плавания зарегистрировано при использовании нагрузки 20\% на фроне экстракта в обеих дозах. Настойка сныти не изменяет результаты данного теста. Препараты сныти неоднозначно влияют на результаты теста экстраполяционного избавления: экстракт и настойка не влияют на количество мышей, которые успешно выполняют тест, но среди выполнивших тест животных время избавления достоверно снижается на фонне экстракта в дозах 100 мг/ка и 1 г/ка (без изменений показателя всей группы). Экстракт в дозе 100 мг/ка достоверно уменьшает количество крыс, которые осущестөляют подныривание, экстракт (1 2/к2) и настойка (1 мл/ка) увеличивают время, необходимое для выполнения теста экстраполяционного избавления крысами. Экстракт и настойка сныти не изменяют выраженность понижения температуры тела и блефрароптоза, вызванных резерпином у крыс. Таким образом, экстракт сныти способен повышать фризическую работоспособность, оказывать умеренное позитивное влияние на когнитивные процессы у мышей (но не у крыс) без существенных изменений депрессивности. Настойка сныти ухудшает результаты теста экстраполяционного избавления в дозе 1 мл/кг, не изменяет их в дозе 5 мл/ке, не влияет на депрессивность и фризическую работоспособность в обеих дозах. 